\title{
Women Entrepreneurs In A Patriarchal Society: Socio-Cultural Preceptions Of Women In Beer Parlour Business In Ibadan, Nigeria
}

\author{
Adebimpe A. Adenugba, PhD \\ Department of Sociology \\ Faculty of the Social Sciences \\ University of Ibadan, Ibadan, Nigeria \\ Tomilola Oladeji, MSc \\ Department of Sociology \\ Faculty of the Social Sciences \\ University of Ibadan, Ibadan, Nigeria \\ Ruth Akhuetie, MSc \\ Department of Sociology and Anthropology \\ Faculty of Social Sciences \\ University of Benin, Benin, Nigeria
}

\begin{abstract}
The number of businesses owned and controlled by women all over the world has continued to rise steadily. However, women entrepreneurs still have to deal with issues relating to their gender as well as acceptance in the society. This study examines the socio-cultural perceptions of women in beer parlour business in Ibadan, Oyo State, Nigeria. The liberal feminist theory was adopted as the theoretical framework for this study. The exploratory survey design was used to collect data from the respondents and the questionnaire as well as in-depth interview formed the instruments for data collection in this study. Both descriptive and inferential statistics such as frequencies and percentages as well as the chi-square served as the data analytical tools. The study concluded that there is no significant association between respondents' age, educational level, marital status as well as religious affiliation and perception towards women in beer parlour business. As a result, it has become imperative to discourage stereotypical perceptions in the society particularly of women in some certain trades.
\end{abstract}

Keywords: Beer parlour business, Entrepreneur, Liberal feminism, Patriarchy, Socio-cultural perception, Ibadan

\section{INTRODUCTION}

Most developing countries have experienced a significant increase in the number of new businesses started by women (Blundel et al, 2010). Generally speaking, the entrepreneurial process is a social process executed by people living in specific cultural and social conditions and for that reason, the positive perception that society has on entrepreneurship of any form (such as the bar business) is a necessary condition to motivate people toward the entrepreneurial process. In Nigeria, bars and beer parlours are highly-stereotyped spaces due to moral, religious and cultural issues, while such social spaces are also perceived by the law enforcement agencies (especially Police) as criminal hide-outs. Indeed, since beer parlours' clientele is male-dominated, the social space is likely to embody conflictual relations that may magnify patriarchy and subordinate women as both women business owners and female 
servers are vulnerable to insults, abuse, physical violence, harassment and perhaps stigmatized as "immoral" within their place of work, even though they are obvious "business owners."

It is important to note that discourses on gender in Nigeria usually slide into an analysis of the disadvantaged position of Nigerian women as they struggle to realize their full potentials in the society. The reason for the greater focus on women rather than men is primarily because of the patriarchal nature of the Nigerian society (Makhbul, 2011). In this regard, it is essential to understand the socio-cultural factors influencing the negative perception of women in beer parlour business. The study focuses on the socio-cultural perceptions of people towards women engagement and ownership of beer parlour business across board, especially in a patriarchal society where men are the central decision makers in economic activities with specific reference to their engagement and ownership of beer parlours within the Ibadan metropolis. It is against this backdrop that the study proposes to examine the socio-cultural perceptions of women in beer parlour business in Ibadan metropolis.

\section{Women Entrepreneurs and Societal Perception}

Abimbola and Agboola (2011) view gender as a force capable of either impeding or facilitating entrepreneurial activities in any society. The issue of gender factor affects women entrepreneurs either positively or negatively, depending on the economy and nation. Prejudice against women entrepreneurs is experienced much more severely in Africa and indeed the developing countries than in developed countries due to oblivious cultural practices, religious bigotry, discrimination and tradition of patriarchal cultures (Thebaud, 2010). According to Naude and Amainniti (2012) gender gaps during the start-up of any entrepreneurial activity is larger in developing economies but tends to be narrower in developed economies. This may be due to many women commencing business out of necessity.

Gender discrimination however still exists against women entrepreneurs and is usually exhibited in different ethnic practices, for example, the Igbos of South-East Nigeria are known to be the foremost entrepreneurial group, when compared to other major ethnic groups in the country. The entrepreneurial activities as practiced among the Igbos give preference to the male child in nurturing for entrepreneurial activities. The male child is given entrepreneurial orientation and training right from the childhood, while the female child is seen to provide future supportive role to her husband or family business. This is evident as argued by Nworah (2011) at the demise of the head of a family (an entrepreneur) in Igbo ethnic group where the ownership and control is transferred to the eldest male child who may even be the least competent. This constitutes a bias against women-entrepreneurs.

\section{THEORETICAL FRAMEWORK}

The Liberal Feminist Theory was adopted for this study. It posits that the sexual division of labor in modern societies divides production in terms of both gender and spheres denoted as "public" and "private." Women are accorded principal responsibility for the private sphere while men are given privileged control over the public sphere (which liberal feminists view as the centre of the true rewards of social life such as money, power, status, freedom, opportunities for growth and self-worth). The fact that women have what access they do to the public sphere is one triumph of the women's movement and of liberal feminism as is the fact that women feel they can make some demands on men to assist in the work of the private sphere. The two spheres constantly interact in the lives of women (more than they do for men), and both spheres are still shaped by patriarchal ideology and sexism, which also are pervasive in contemporary mass media (Blakely, 2008; Press, 2009). 
According to Ritzer \& Stepnisky (2013) Liberal feminism, thus, rests on the beliefs that:

(1) All human beings have certain essential features-capacities for reason, moral agency, and self-actualization

(2) The exercise of these capacities can be secured through legal recognition of universal rights,

(3) The inequalities between men and women assigned by sex are social constructions having no basis in "nature," and

(4) Social change for equality can be produced by an organized appeal to a reasonable public and the use of the state.

Hierarchical and imbalanced power relations are often legitimized through beliefs of false consciousness, social practices and other institutions such as religion, kinship and family system, media, law and even the state. Also, at the household level, family patriarchal values as well as masculinity and femininity character stereotypes are reinforced through the process of gender socialization. Therefore, patriarchy is the root cause of women's discriminatory practices against their participation in economic activities. At the household level, unequal power relations placed women at a disadvantaged position. Consequently, a process of subjugation of women in informal sector such as the beer parlour business is perpetrated. Women in such business often suffer social rejection or are perceived by their male counterparts as being unfeminine. Women who engage in the sales of beer are never recognized as entrepreneurs no matter how successful they are because of the socio-cultural perceptions held against it

\section{Materials and Methods}

Study Location: Ibadan municipality which is located in the south-western part of Nigeria and is the capital city of Oyo State was chosen for the study. Ibadan is regarded as the largest indigenous city in tropical Africa and as a result of its historical antecedents, Ibadan has continuously witnessed influx of people which have contributed to its rapid growth both in population and physical expansion to cover a very large land mass (Ajayi et al, 2012). It is also a major commercial, industrial, and administrative centre.

Research Design: The study adopted exploratory survey design to collect quantitative data from the male customers at the beer parlours in the study area. In addition to the survey method, the study complemented quantitative research with in-depth interviews. The utilization of two methods is to remove bias and enrich the work by making the findings more robust. These methods generated data on the socio-cultural perceptions of women in beer parlour business in Ibadan.

Study Population: The population of the study comprised all stakeholders in the beer parlours within the study area which include the women in beer parlour business, both their male and female clienteles (it may also include the non-consumers) as well as some police officers and clergy-men in the study location. The people living close to the beer parlours in the study location were also included to examine how they perceive the women in beer parlour business.

Sample size and Sampling Techniques: The technique utilized in this study was the multistage sampling which comprised three stages. In the first stage, the selection of Ibadan as the study location was through purposive sampling method for the sake of convenience. The second stage involved the identification of four areas in Ibadan with the largest concentration of beer parlours; they included Eko-tedo, Onireke, Mokola/roundabout and Dugbe and the third and final stage involved the selection of the various beer parlours in the study areas owned and managed by women, their male and female customers, the police officers in the 
area and those living in the neighbourhood. Three hundred and seventy-five copies of questionnaire were administered to the male customers, nineteen in-depth interviews were conducted with the women in beer parlour business, five with female customers, five IDIs were also conducted with neighbours, five with police officers and five with the religious clerics. The in-depth interview conducted with the female customers was to enable the researcher to probe further so as to complement the information obtained through the questionnaire that was administered to male customers.

Validity and Reliability of Research Instruments: In order to achieve the objectives of the study, the validity and reliability of the methods of data collection were given full attention. In an attempt to ensure that the instruments of data collection measure what they purport to measure; face validity type was adopted. In addition to this, a pre-test of the instruments was carried out before the actual field study in order to assess its validity. Furthermore, to ensure that the data collected are internally consistent, the reliability coefficient of the measures of this study at Chronbach's alpha $\alpha$ is 0.7. This is an indication that the variable measurements strongly agree with one another.

Methods of Data Analysis: Following the triangulation method the study adopted, the analysis of the study was done according to the methods used to collect the data from the various respondents. To this end, quantitative data were statistically analyzed by relevant descriptive univariate and bivariate analyses using frequencies, percentages, mean, charts, crosstabulation and chi-square as appropriate. Hypotheses were tested using cross-tabs, chi square and Pearson Correlation at $\mathrm{P}<0.05$ and $\mathrm{P}<0.01$ level of significance respectively. Here, the Pearson correlation was found to be positive and very strong correlation at 0.94 , an indication that the two variables were strongly positively related. For the qualitative data collected through IDIs, open code content analysis was adopted to transcribe recordings followed by examination and isolation of various responses according to the objective of the study. Verbatim quotation method was used as appropriate to complement the quantitative method of data analysis after translation from local languages into English Language. The process began with proper translation and transcription of the data from the tape recorder.

Ethical Considerations: In this study, the international standard ethics for research was adhered to. The opinions of the respondents were sought and the objective of the research was clearly explained to prospective participants before they were interviewed. They were informed of their right to voluntary participation and withdrawal from the study if they wish.

\section{Socio-demographic Characteristics}

\section{RESULTS AND DISCUSSION OF FINDINGS}

Data presented in Table 1 indicates that $100 \%$ of the respondents were males. In terms of age, $18.7 \%$ of the respondents indicated that they were between the ages of $18-25$ years, $19.7 \%$ were between the ages of $26-30$ years, $23.5 \%$ were between the ages of $31-35$ years, $13.1 \%$ between the ages of 36-40 years, $9.6 \%$ between the ages of $41-45$ years, while $15.6 \%$ indicated that they were 45 years and above. The mean age of the respondents is 33.8 years old. This implies that the largest age group of the respondents is 31-35 years $(23.5 \%)$ with strong indication that the respondents are adults in respect to their views on the phenomenon under investigation and majority of them fall within active age. With regards to marital status of the respondents, the table shows that $46.9 \%$ were single, $43.2 \%$ were married, $5.1 \%$ were separated or divorced and $4.8 \%$ were widowed. This is an indication that majority of the respondents were unmarried (46.9\%) and therefore did not have marital and financial responsibilities. Regarding educational attainment, $7.2 \%$ of the respondents had no formal education, $6.4 \%$ had primary school, $22.4 \%$ had secondary school education, while $64.0 \%$ had 
tertiary school education. This suggests that most of the respondents had formal education which is a major requirement in modern society. They were also probably trying to ease their tension after the day's hassles.

In terms of the religious affiliation of the respondents, $4.3 \%$ of them were African Traditional Religion practitioners (ATR), $56.3 \%$ were Christians, $37.3 \%$ were Muslims and only $2.1 \%$ indicated other religious affiliation. With regards to the occupation of the respondents, $27.7 \%$ of them were civil servants, $12.3 \%$ were in private employment, $17.3 \%$ were self-employed, $23.5 \%$ were students, $9.3 \%$ were traders, $6.4 \%$ were artisans, $2.9 \%$ were unemployed, while $5.0 \%$ were retirees. This also means that majority of the respondents were civil servants as against only $2.9 \%$ who were unemployed.

Also, in regards to ethnic origin, Table 1 indicated that $76.0 \%$ of the respondents were Yoruba, $10.7 \%$ were Igbo, $5.6 \%$ were Hausa, while $7.7 \%$ indicated others. This implies that the largest ethnic group of origin of the respondents was Yoruba because the study was situated and carried out in predominantly Yoruba speaking areas in Ibadan. As regards the number of years respondents have resided in Ibadan, $8.3 \%$ of them indicated that they had resided in Ibadan for less than one year, $20.3 \%$ of them said they had resided in Ibadan for $1-5$ years, $57.1 \%$ for 6 years and above, while $14.4 \%$ indicated non-resident/visitors status. This is an indication that the largest group of respondents had resided in Ibadan for 6 years and above. 
Table 1 Distribution of Socio-demographic Characteristics of Respondents

\begin{tabular}{|c|c|c|c|}
\hline Characteristics & Responses & Frequency $(\mathrm{N}=375)$ & Percentages (\%) \\
\hline Sex & Male & 375 & 100 \\
\hline Age & $\begin{array}{l}18-25 \\
26-30 \\
31-35 \\
36-40 \\
41-45 \\
45>\end{array}$ & $\begin{array}{l}70 \\
74 \\
88 \\
49 \\
36 \\
58\end{array}$ & $\begin{array}{c}18.7 \\
19.7 \\
23.5 \\
13.1 \\
9.6 \\
15.5\end{array}$ \\
\hline Marital Status & $\begin{array}{l}\text { Single } \\
\text { Married } \\
\text { Separated/Divorced } \\
\text { Widower }\end{array}$ & $\begin{array}{c}176 \\
162 \\
19 \\
18\end{array}$ & $\begin{array}{c}46.9 \\
43.2 \\
5.1 \\
4.8\end{array}$ \\
\hline $\begin{array}{l}\text { Highest } \\
\text { Educational } \\
\text { Attainment }\end{array}$ & $\begin{array}{l}\text { No formal education } \\
\text { Primary school } \\
\text { Secondary school } \\
\text { Tertiary }\end{array}$ & $\begin{array}{c}27 \\
24 \\
84 \\
240\end{array}$ & $\begin{array}{c}7.2 \\
6.4 \\
22.4 \\
64.0\end{array}$ \\
\hline $\begin{array}{l}\text { Religion } \\
\text { Affiliation }\end{array}$ & $\begin{array}{l}\text { ATR } \\
\text { Christianity } \\
\text { Islam } \\
\text { Others }\end{array}$ & $\begin{array}{c}16 \\
211 \\
140 \\
8\end{array}$ & $\begin{array}{c}4.3 \\
56.3 \\
37.3 \\
2.1\end{array}$ \\
\hline Occupation & $\begin{array}{l}\text { Civil Servant } \\
\text { Private employment } \\
\text { Self-employed } \\
\text { Students } \\
\text { Trader } \\
\text { Artisans } \\
\text { Unemployed } \\
\text { Retiree }\end{array}$ & $\begin{array}{c}104 \\
46 \\
65 \\
88 \\
35 \\
24 \\
11 \\
2\end{array}$ & $\begin{array}{c}27.7 \\
12.3 \\
17.3 \\
23.5 \\
9.3 \\
6.4 \\
2.9 \\
5 \\
\end{array}$ \\
\hline Ethnic Origin & $\begin{array}{l}\text { Yoruba } \\
\text { Igbo } \\
\text { Hausa } \\
\text { Others }\end{array}$ & $\begin{array}{c}285 \\
40 \\
21 \\
29\end{array}$ & $\begin{array}{c}76.0 \\
10.7 \\
5.6 \\
7.7\end{array}$ \\
\hline $\begin{array}{l}\text { Years of } \\
\text { Residence in } \\
\text { Ibadan }\end{array}$ & $\begin{array}{l}<1 \text { year } \\
1-5 \text { Years } \\
6 \text { years \& above } \\
\text { Non-Residents/visitors }\end{array}$ & $\begin{array}{c}31 \\
76 \\
214 \\
54\end{array}$ & $\begin{array}{c}8.3 \\
20.3 \\
57.1 \\
14.4\end{array}$ \\
\hline
\end{tabular}

Source: Field Survey (2017)

\section{The Socio-Cultural Perceptions of Women in Beer Parlour Business}

In order to examine the socio-cultural perceptions of women in beer parlour business relative to those owned and controlled by men, respondents were asked about their perception of the women in beer parlour business' Table 2 showed that $35.2 \%$ of the respondents perceived that they were 'promiscuous', 20.0\% considered them as 'business women', 14.4\% indicated 'flirts', $8.0 \%$ perceived that they were 'morally upright', 13.6\% regarded them as 'husband snatcher', while $3.2 \%$ indicated 'others'.

Respondents were also asked whether they could marry a lady who operates beer parlour business. Table 2 indicates that $36.0 \%$ of the respondents said 'yes' while $55.2 \%$ indicated 'no'. Obviously, majority of the respondents were of the view that they could not marry a woman who is operating a beer parlour business. Furthermore, respondents were asked to indicate the reasons for this, $26.7 \%$ of them opined that it was because 'the business is considered as indecent', $10.4 \%$ said 'they were prostitutes', $17.6 \%$ indicated that 'they were free-ladies', 1.8\% of them indicated others while the remaining $37.6 \%$ of them indicated nothing. This is 
consonance in with the findings by Halkias et al., (2011) that gender and culture impede the economic potential of women as entrepreneurs and impact negatively on their enterprise.

Moreover, respondents were asked whether they had ever come to the beer parlour with their spouses. The result shows that $41.9 \%$ of them indicated 'yes', $53.9 \%$ of them said 'no', while only $4.3 \%$ of them had no response. The implication here is that majority of the respondents do not go to beer parlour with their spouses. Also, in ascertaining whether respondents could allow their spouses to operate a beer parlour business, $30.1 \%$ said 'yes' to that effect, $57.3 \%$ indicated 'no'. This implies that most of the respondents would not allow their wives to own or operate beer parlour business. This may be due largely to how the business is perceived by the people.

Furthermore, in Table 2, respondents were asked to indicate why they would not allow their spouses to operate beer parlour business. $5.6 \%$ of them said it is because 'such women were regarded as 'prostitutes', $31.7 \%$ indicated that 'they won't be good role models to the children', $19.5 \%$ were of the opinion that 'they don't usually have a stable home, while $6.1 \%$ of them indicated other reasons. This invariably suggests that majority of the respondents subscribed to the fact that 'they won't be good role models to children'. In a similar vein, respondents were asked whether they would encourage any female relative of theirs who desired to start a beer parlour business, $34.4 \%$ of the respondents said 'yes', while 56.8\% indicated 'no.' From the result, majority of the respondents would not encourage female relatives of theirs to start beer parlour business. Also, respondents who indicated 'no' were further asked the reasons for their answer, while $10.1 \%$ said it was because of 'prostitution', $41.9 \%$ indicated 'bad role model', $9.1 \%$ said 'respectful' but only $1.6 \%$ indicated 'others'. This finding is supported in the study by Abimbola and Agboola (2011) which shows that gender as a force is capable of either impeding or facilitating entrepreneurial activities of women.

With regards, to their perception, respondents were asked if cultural practices of the respondents forbid a woman from operating beer parlour business, $28.5 \%$ of them indicated 'yes', while $69.6 \%$ said 'no'. Also, another question was asked whether their religious practices forbid a woman from operating a beer parlour business, 59.2\% of them said 'yes' while $37.9 \%$ indicated 'no'. Also, questions were asked whether their personal conviction support a woman to operate beer parlour business, $43.7 \%$ of them said 'yes' while $52.8 \%$ of them indicated 'no'. In the same vein, respondents were asked whether men make passes at women in beer parlour business. While $68.0 \%$ of the respondents said 'yes', $28.5 \%$ of them indicated ' $n o$ '. In another view, a question was asked to ascertain whether respondents had ever made a pass at any woman in beer parlour business, $34.9 \%$ of them said 'yes' while $50.1 \%$ of them indicated 'no'. Again, respondents who said 'they had made pass' were asked to indicate how those women reacted. While $21.1 \%$ said they 'agreed,' $8.0 \%$ said they 'rebuffed,' $11.5 \%$ of them indicated they were 'insulted' but $8.8 \%$ of them indicated others. 
Table 2: Socio-Cultural Perceptions towards Women in Beer Parlour Business

\begin{tabular}{|c|c|c|c|}
\hline Questions & Responses & Frequency $(n=375)$ & Percent \\
\hline $\begin{array}{l}\text { How do you perceive the } \\
\text { women in beer parlour } \\
\text { business? }\end{array}$ & $\begin{array}{ll}\text { - } & \text { Promiscuous } \\
\text { - } & \text { Business women } \\
\text { - } & \text { Flirt } \\
\text { - } & \text { Morally Upright } \\
\text { - } & \text { Husband } \\
& \text { snatcher } \\
\text { - } & \text { Others } \\
\text { - } & \text { N/A } \\
\end{array}$ & $\begin{array}{c}132 \\
75 \\
\\
54 \\
30 \\
\\
51 \\
12 \\
21\end{array}$ & $\begin{array}{c}35.2 \\
20.0 \\
\\
14.4 \\
8.0 \\
\\
13.6 \\
3.2 \\
5.6\end{array}$ \\
\hline $\begin{array}{l}\text { Can you marry a lady who } \\
\text { operates a beer parlour? }\end{array}$ & $\begin{array}{ll}\text { - } & \text { Yes } \\
\text { - } & \text { No } \\
\text { - } & \mathrm{N} / \mathrm{A}\end{array}$ & $\begin{array}{c}135 \\
207 \\
33\end{array}$ & $\begin{array}{c}36.0 \\
55.2 \\
8.8\end{array}$ \\
\hline If no, why? & $\begin{array}{l}\text { The business is indecent } \\
\text { They are prostitutes } \\
\text { They are free-ladies } \\
\text { Others } \\
\text { N/A }\end{array}$ & $\begin{array}{c}100 \\
39 \\
66 \\
29 \\
141 \\
\end{array}$ & $\begin{array}{c}26.7 \\
10.4 \\
17.6 \\
1.8 \\
37.6\end{array}$ \\
\hline $\begin{array}{l}\text { Have you ever come to the } \\
\text { beer parlour with your } \\
\text { spouse? }\end{array}$ & $\begin{array}{ll}\text { - } & \text { Yes } \\
\text { - } & \text { No } \\
\text { - } & \text { N/A } \\
\end{array}$ & $\begin{array}{c}157 \\
202 \\
16 \\
\end{array}$ & $\begin{array}{c}41.9 \\
53.9 \\
4.3 \\
\end{array}$ \\
\hline $\begin{array}{l}\text { Can you allow your spouse to } \\
\text { operate a beer parlour } \\
\text { business? }\end{array}$ & $\begin{array}{ll}\text { - } & \text { Yes } \\
\text { - } & \text { No } \\
\text { - } & \mathrm{N} / \mathrm{A} \\
\end{array}$ & $\begin{array}{c}113 \\
215 \\
47 \\
\end{array}$ & $\begin{array}{l}30.1 \\
57.3 \\
12.5\end{array}$ \\
\hline If no, why? & $\begin{array}{l}\text { They are prostitutes } \\
\text { They won't be good role } \\
\text { models to children } \\
\text { They don't usually have } \\
\text { a stable home } \\
\text { Others } \\
\text { N/A }\end{array}$ & $\begin{array}{c}21 \\
119 \\
73 \\
\\
23 \\
139 \\
\end{array}$ & $\begin{array}{c}5.6 \\
31.7 \\
19.5 \\
6.1 \\
37.1\end{array}$ \\
\hline $\begin{array}{l}\text { Would you encourage any } \\
\text { woman-relative of yours who } \\
\text { wants to start beer parlour } \\
\text { business? }\end{array}$ & $\begin{array}{ll}\text { - } & \text { Yes } \\
\text { - } & \text { No } \\
\text { - } & \text { N/A }\end{array}$ & $\begin{array}{c}129 \\
213 \\
33\end{array}$ & $\begin{array}{c}34.4 \\
56.8 \\
8.8\end{array}$ \\
\hline If no, why? Because they are: & $\begin{array}{ll}\text { - } & \text { Prostitutes } \\
\text { - } & \text { Bad role model } \\
\text { - } & \text { Respectful } \\
\text { - } & \text { Others } \\
\text { - } & \text { N/A } \\
\end{array}$ & $\begin{array}{c}38 \\
157 \\
34 \\
6 \\
140 \\
\end{array}$ & $\begin{array}{c}10.1 \\
41.9 \\
9.1 \\
1.6 \\
37.3 \\
\end{array}$ \\
\hline $\begin{array}{l}\text { Does your culture forbid a } \\
\text { woman from operating beer } \\
\text { parlour business? }\end{array}$ & $\begin{array}{ll}- & \text { Yes } \\
- & \text { No } \\
- & \text { N/A } \\
\end{array}$ & $\begin{array}{c}107 \\
261 \\
7\end{array}$ & $\begin{array}{c}28.5 \\
69.6 \\
1.9 \\
\end{array}$ \\
\hline $\begin{array}{l}\text { Does your religion forbid a } \\
\text { woman from operating a beer } \\
\text { parlour business? }\end{array}$ & $\begin{array}{ll}- & \text { Yes } \\
- & \text { No } \\
- & \text { N/A } \\
\end{array}$ & $\begin{array}{c}222 \\
142 \\
11 \\
\end{array}$ & $\begin{array}{c}59.2 \\
37.9 \\
2.9 \\
\end{array}$ \\
\hline $\begin{array}{l}\text { Does your personal conviction } \\
\text { support a woman operating } \\
\text { beer parlour business? }\end{array}$ & $\begin{array}{ll} & \text { Yes } \\
- & \text { No } \\
\text { - } & \text { N/A } \\
\end{array}$ & $\begin{array}{c}164 \\
198 \\
13 \\
\end{array}$ & $\begin{array}{c}43.7 \\
52.8 \\
3.5 \\
\end{array}$ \\
\hline $\begin{array}{l}\text { Do men make passes at } \\
\text { women who operate beer } \\
\text { parlour business? }\end{array}$ & $\begin{array}{ll}- & \text { Yes } \\
- & \text { No } \\
- & \text { N/A } \\
\end{array}$ & $\begin{array}{c}255 \\
107 \\
13 \\
\end{array}$ & $\begin{array}{c}68.0 \\
28.5 \\
3.5\end{array}$ \\
\hline
\end{tabular}




\begin{tabular}{|l|l|c|c|}
\hline If yes, what was her reaction? & $\bullet$ Agreed & 79 & 21.1 \\
& $\bullet$ Rebuffed & 30 & 8.0 \\
& $\bullet$ Insult & 43 & 11.5 \\
& $\bullet$ Others & 33 & 8.8 \\
& $\bullet$ N/A & 190 & 50.7 \\
\hline
\end{tabular}

Source: Field Survey (2017) **NA=Not Applicable

From the Table 2 above, it can be inferred that women in beer parlour business are mostly perceived negatively as husband-snatchers, promiscuous, prostitutes, free-ladies and in all as indecent. However, some respondents view these women in a positive light as businesswomen. Similarly, this is further supported by the responses from the interviews conducted with the female customers at the beer parlours, police officers and those living close to the beer joints. For instance, a neighbour said he views this business as being indecent for any woman but majority of them engage in the business as a result of economic frustration or poverty.

...to me, I feel beer parlour business is indecent for a responsible woman but as a result

of one reason or the other they do the business. But I perceive these women decide to

go into this business as a result of frustration and poverty

(IDI/Male/Neighbour/Agriculturist/63 years/Ibadan/2017).

Similarly, another interviewee also explained that he sees these women as good businesswomen who know what people would want to buy and they provide it. He discussed further that, these women normally have marital problems because majority of them are of loose characters. He said:

They are good business people, because they know what people want and they provide it, they get their money without any negative feelings. Well, it's possible that some of them might not be in stable marriages either they are divorced or married but separated or widowed but I think they are just business people, although they may have issues but they are business people. Hmmmmm well, however, (silent for a while) quite a number of them are women of loose character (IDI/Male/Neighbour/32years/Ibadan/2017).

In addition to what was said above, a police officer was also of the opinion that, beer parlour business is similar to every legal business in Nigeria, hence its operators are businesswomen. Shedding more light on the issue, another police officer averred that:

There is no barrier in it, beer parlor business is a business and this is because any woman in beer parlour business is in it in order to earn her daily bread. Also, the Nigeria law does not have any ban or prohibition on the business. So, to the law enforcement agency there is no law that allows the police officers to lay ban on the business. Hence, women who are in beer parlour business are businesswomen (IDI/Male/Police officer/35years/Ibadan/2017).

On a contrary note, a policewoman explained that although the law recognizes these women as business owners, she personally dislikes them because they only engage in the business to cover-up their indecent behaviour. She was also of the opinion that most women in beer parlour business habour criminals. She elaborated further on the issue that:

Although, the law recognizes these women as business owners, I personally dislike the business because majority of those women are prostitutes, they entered into the business as an opportunity to step-up or commercialize their indecent behaviour. Also, majority of them harbour criminals a lot (IDI/Female Police officer (ASP)/50years/Ibadan/2017). 
A female customer noted that although women in beer parlour business are generally referred to as prostitutes because of the problems they encounter in their marital life which makes most of them to engage in extra-marital relationships, on a closer rapport with these women, one would observe their good qualities. She revealed:

If one is not very close to these women, one is likely to have a negative perception about them, which explains why they are generally regarded as prostitutes. They don't usually have stable homes and they often engage in extra-marital affairs which explains why they often engage in husband-snatching. But I can't say they don't have any positive side. These women tend to have some qualities that are satisfactory, for instance; they are very caring and jovial. But generally the perception I have towards them is that of husband-snatching, and they also engage in quite a number of immoral behaviour (IDI/37years/Female customer/Ibadan/2017).

In addition to what has been said above, another police officer noted that since no Nigeria law prohibits the beer parlour business, women who engage in it are thus business owners, because they do so to earn income for their livelihood. Shedding more light on the issue, another police officer averred that:

There is no barrier in it, beer parlor business is a business and this is because any woman in beer parlour business is in it in order to earn her daily bread. Also, the Nigeria law does not have any ban or prohibition on the business. So, to the law enforcement agency there is no law that allows the police officers to lay ban on the business (IDI/Male/Police officer/35years/Ibadan 2017).

The statements above further support the perceptions of the respondents in Table 2. Women in beer parlour business are perceived positively on one hand as business women or business owners and on the other, negatively as prostitutes, husband-snatchers, and women of loose character who engage in business to cover-up indecent behaviours and aid activities of criminals. Furthermore, viewing the socio-cultural perceptions of women in beer parlour business from religious perspectives, the following responses categorically opined that Islamic religion has absolutely no tolerance for the consumption of alcohol, hence, since drinking is forbidden, selling of alcohol by women is also forbidden. An Islamic cleric interviewed said:

The religion has absolutely no tolerance for the consumption of alcohol, because when drunk, you cannot pray and once the religion is against the act, it is also against the sales too, irrespective of the gender of the person selling it. The holy Quran chapter 4 verses 90-91 emphasizes the position of Allah on any alcoholic drink. However, I think it is even more sinful when a woman is selling because it can aid and abet other forms of sin like fornication and adultery (IDI/Islamic cleric/48years/Ibadan/2017).

A Pentecostal cleric further supported what had been said by the imam. Both the sale and consumption of beer are prohibited, members of the church who are caught in any of these acts are excommunicated from the church and those who are not caught in it but are guilty of it are viewed as hypocrites. Expatiating further he said:

In Proverbs 20:1, the bible forbids the consumption of alcohol hence, in the Pentecostal churches, both the sale and consumption of beer are prohibited, those who are caught drinking or selling irrespective of their gender are ex-communicated but despite the stand of the church on the consumption and sale of alcohol, some people still engage in it and this act makes them to be hypocrites. It is a business that emerged as a result of moral decadence. For people who go into the business it is both for economic and spiritual waywardness. To me, I feel the sale of beer is an attempt to influence people negatively and although those women may get their daily income from the selling of 
beer, but it is done at the detriment of the society. It also promotes other sinful activities like promiscuity (IDI/Pentecostal cleric/39years/Ibadan/2017).

The Orthodox Church is liberal as it does not have any negative perceptions towards the people drinking or selling alcoholic drinks, insofar it is done with moderation. Contrary to opinion of the respondents above, an Orthodox cleric said:

Drinking of alcohol is not totally frowned at as it is often served sometimes during ceremonies in church, but it is expected to be done with moderation, so the church does not totally promote the consumption of alcohol I feel the church does not have serious stand on the consumption of alcohol; so far it is not done outside moderation. It is mostly drunk by members of the church avoiding sweet things. Beer parlour business is a very liberal business, it does not demand energy, it is very feminine in nature and mostly consumed by men. The business cannot be restricted; in as much as it does not endanger or constitute insecurity to the society. It is the demand for beer that calls for supply of it by those women; this means if people were not demanding for it, they will not be selling it (IDI/Catholic cleric/48years/Ibadan/2017)

From the responses above, it can be deduced that there are various religious arguments in support of and against the sale of beer by women. The Pentecostal churches and Islamic sect frown at both the consumption and sale of alcoholic drinks, while the orthodox churches on the other hand are more liberal towards women selling beer and those who drink it. Nigeria is a secular state where people can sell and buy anything within the ambit of the law, hence, the selling and buying of alcohol is not restricted by law in any of the study areas.

\section{Hypotheses Testing}

The hypotheses in this study were tested using the chi-square test output result from the SPSS. Four hypotheses were tested in this study. They include;

1. There is no association between age of respondents and perception towards women in beer parlour business.

2. There is no association between the educational level and perception towards women in beer parlour business.

3. There is no association between marital status and perception towards women in beer parlour business.

4. There is no association between religious affiliation and perception towards women in beer parlour business.

Hyothesis 1: There is no association between age of respondents and perception towards women in beer parlour business.

The contigency table for respondents' age and perception towards women in beer parlour business at chi square of 21.6, degree of freedom 25 and p-value equal to 0.659 ( $>>0.05$ ) indicated that despite the negative perceptions towards women in beer parlour business there was no significant association between respondent's age and perception towards women in beer parlour business. This indicates that regardless of the age of the respondents, the perception towards women in the beer parlour business remains the same. The mean age of the respondents is 33.8\% years old, this shows that majority of the respondents were young adults, who were probably more enlightened and civilized. Hence, they did not perceive the women in the beer parlour business negatively, as against if the majority of the respondents were old people. 
Table 3: Respondents' Age group and Perception of Women in Beer Parlour Business

\begin{tabular}{|c|c|c|c|c|c|c|c|c|c|c|}
\hline Age & Respondents' & erception of & omen in be & parlour bu & hess & & & & & \\
\hline & Promiscuous & $\begin{array}{l}\text { Business } \\
\text { women }\end{array}$ & Flirt & $\begin{array}{l}\text { Morally } \\
\text { upright }\end{array}$ & $\begin{array}{l}\text { Husband } \\
\text { snatcher }\end{array}$ & Others & Total & $\begin{array}{c}\text { Chi } \\
\text { Square }\end{array}$ & Df & P-value \\
\hline $18-25$ & 9 (14.3) & $25(39.7)$ & $15(23.8)$ & $4(6.3)$ & 7 (11.1) & $3(4.8)$ & 63 & & & \\
\hline $26-30$ & $15(20.5)$ & $25(34.2)$ & 9 (12.3) & $11(15.1)$ & $12(16.4)$ & $1(1.4)$ & 73 & & & \\
\hline $31-35$ & $21(25.3)$ & 27 (32.2) & $11(13.3)$ & $8(9.6)$ & $12(14.5)$ & $4(4.8)$ & 83 & 21.6 & 25 & 0.659 \\
\hline $36-40$ & $9(20.5)$ & $15(34.1)$ & $6(13.6)$ & $4(9.1)$ & $9(20.5)$ & $1(2.3)$ & 44 & & & \\
\hline $41-45$ & $10(29.4)$ & $12(35.3)$ & 5 (14.7) & $1(2.9)$ & 5 (14.7) & $1(2.9)$ & 34 & & & \\
\hline $45>$ & $11(19.3)$ & $28(49.1)$ & $8(14.0)$ & $2(3.5)$ & $6(10.5)$ & $2(3.5)$ & 57 & & & \\
\hline Total & $75(21.2)$ & $132(37.3)$ & 54 (15.3) & $30(8.5)$ & $51(14.4)$ & $12(3.4)$ & 354 & & & \\
\hline
\end{tabular}

\section{Source: SPSS chi-square test output result}

Hyothesis 2: There is no association between the educational level and perception towards women in beer parlour business.

A cursory observation of the association between educational level of respondents and perception of women in beer parlour business was examined. Table 4 shows that there was no association between respondents' education level and perception of women in beer parlour business at chi square of 22.2, degree of freedom 15 and p-value equal to 0.103 ( $p>0.05)$. This implies that the level of educational attainment of the respondents does not determine or change their perception towards women in beer parlour business. Majority $(64.0 \%)$ of the respondents had formal education and hence were enlightened and liberal.

Table 4: Respondents' Educational level and Perception of Women in Beer Parlour Business

\begin{tabular}{|c|c|c|c|c|c|c|c|c|c|c|}
\hline \multirow[t]{2}{*}{ Education level } & \multicolumn{10}{|c|}{ Respondents' Perception of women in beer parlour business } \\
\hline & Promiscuous & $\begin{array}{l}\text { Business } \\
\text { women }\end{array}$ & Flirt & $\begin{array}{l}\text { Morally } \\
\text { upright }\end{array}$ & $\begin{array}{l}\text { husband } \\
\text { snatcher }\end{array}$ & Others & Total & $\begin{array}{c}\text { Chi } \\
\text { square }\end{array}$ & $\overline{\mathrm{Df}}$ & $\begin{array}{c}\text { P- } \\
\text { value }\end{array}$ \\
\hline $\begin{array}{l}\text { No formal } \\
\text { education }\end{array}$ & $7(26.9)$ & $7(26.9)$ & $3(11.5)$ & $3(11.5)$ & $5(19.2)$ & $1(3.8)$ & 26 & & & \\
\hline Primary & $9(39.1)$ & $5(21.7)$ & $5(21.7)$ & 0 & $4(17.4)$ & 0 & 23 & & & \\
\hline Secondary & $12(15.2)$ & $31(39.2)$ & $8(10.1)$ & $10(12.7)$ & $17(21.5)$ & $1(1.3)$ & 79 & 22.2 & 15 & 0.13 \\
\hline Tertiary & $47(20.8)$ & 89 (39.2) & 38 (16.8) & $17(7.5)$ & 25 (11.1) & $10(4.4)$ & 226 & & & \\
\hline Total & $75(21.2)$ & $132(37.3)$ & $54(15.3)$ & $30(8.5)$ & $51(14.4)$ & $12(3.4)$ & 354 & & & \\
\hline
\end{tabular}

\section{Source: SPSS chi-square test output result}

Hyothesis 3: There is no association between marital status and perception towards women in beer parlour business.

Association between respondents marital status and perception towards women in beer parlour business on Table 5 shows that there was no association between respondents' marital status and perception of women in beer parlour business at chi square of 22.5, degree of freedom 15 and p-value equal to $0.094(\mathrm{p}>0.05)$. This invariably suggests that despite respondents' negative perceptions of women in beer parlour business, marital status did not have significant association with the perception towards women in beer parlour business. 
Adenugba, A. A., Oladeji, T., \& Akhuetie, R. (2018). Women Entrepreneurs In A Patriarchal Society: Socio-Cultural Preceptions Of Women In Beer Parlour Business In Ibadan, Nigeria. Advances in Social Sciences Research Journal, 5(11) 460-474.

Table 5: Respondents' Marital Status and Perception of Women in Beer Parlour Business

\begin{tabular}{|c|c|c|c|c|c|c|c|c|c|c|}
\hline \multirow[t]{2}{*}{ Marital Status } & \multicolumn{10}{|c|}{ Respondents' Perception of women in beer parlour business } \\
\hline & Promiscuous & $\begin{array}{l}\text { Business } \\
\text { women }\end{array}$ & Flirt & $\begin{array}{l}\text { Morally } \\
\text { upright }\end{array}$ & $\begin{array}{l}\text { husband } \\
\text { snatcher }\end{array}$ & Others & Total & $\begin{array}{c}\text { Chi } \\
\text { square }\end{array}$ & Df & $\begin{array}{c}\mathrm{P}- \\
\text { value }\end{array}$ \\
\hline Single & 25 (16.7) & $54(36.0)$ & $28(18.7)$ & $17(11.3)$ & $20(13.3)$ & $6(4.0)$ & 150 & & & \\
\hline Married & $40(23.8)$ & $69(41.1)$ & $19(11.3)$ & $8(4.8)$ & $26(15.5)$ & $6(3.6)$ & 168 & & & \\
\hline $\begin{array}{l}\text { Separated/ } \\
\text { Divorced }\end{array}$ & $3(16.7)$ & $7(38.9)$ & $4(22.2)$ & $1(5.6)$ & $3(16.7)$ & 0 & 18 & 22.5 & 15 & 0.094 \\
\hline $\begin{array}{l}\text { Widow/ } \\
\text { Widower }\end{array}$ & $7(38.9)$ & $2(11.1)$ & $3(16.7)$ & $4(22.2)$ & $2(11.1)$ & 0 & 18 & & & \\
\hline Total & $75(21.2)$ & $132(37.3)$ & $54(15.3)$ & $30(8.5)$ & $51(14.4)$ & $12(3.4)$ & 354 & & & \\
\hline
\end{tabular}

\section{Source: SPSS chi-square test output result}

Hypothesis 4: There is no association between religious affiliation and perception towards women in beer parlour business.

Table 6 shows the association between respondents' religious affiliation and perceptions of women in beer parlour business at chi square of 10.6, degree of freedom 15 and p-value equal to $0.779(\mathrm{p}>0.05)$. There is no significant association between the respondents' religious affiliation and perception of women in beer parlour business. This means no religion was strong enough to influence the respondents' perception, this is because religion today accommodates several deviations that would not have been condoned in the past. Also, the study was carried out in South-west where religion is more flexible when compared to the Northern part of the country where religion is very rigid. Hence, the drinking and selling of beer is prohibited especially among muslims. In addition to this, the study was conducted in the urban centre where people were likely to accommodate freedom of women to engage in such business as a result of modernity.

\section{Table 6: Respondents' Religious affiliation on Perception of Women in Beer Parlour Business}

\begin{tabular}{|c|c|c|c|c|c|c|c|c|c|c|}
\hline Religion & espondents' P & ception of $\mathrm{w}$ & men in bee & arlour bus & & & & & & \\
\hline & Promiscuous & $\begin{array}{l}\text { Business } \\
\text { Women }\end{array}$ & Flirt & $\begin{array}{l}\text { Morally } \\
\text { upright }\end{array}$ & $\begin{array}{l}\text { Husband } \\
\text { snatcher }\end{array}$ & Others & Total & $\begin{array}{c}\text { Chi } \\
\text { Square }\end{array}$ & Df & P-Value \\
\hline ATR & $4(26.7)$ & 7 (46.7) & $2(13.3)$ & 0 & $1(6.7)$ & $1(6.7)$ & 15 & & & \\
\hline Christianity & $45(22.7)$ & 77 (38.9) & $27(13.6)$ & $16(8.1)$ & 27 (13.6) & $6(3.0)$ & 198 & & & \\
\hline Islam & $25(18.8)$ & $46(34.6)$ & $23(17.3)$ & $14(10.5)$ & $20(15.0)$ & $5(3.8)$ & 133 & 10.6 & 15 & 0.779 \\
\hline Others & $1(12.5)$ & $2(25.0)$ & $2(25.0)$ & 0 & $3(37.5)$ & 0 & 8 & & & \\
\hline Total & 75 (21.2) & $132(37.3)$ & $54(15.3)$ & $30(8.5)$ & $51(14.4)$ & $12(3.4)$ & 354 & & & \\
\hline
\end{tabular}

Source: SPSS chi-square test output result

\section{THEORETICAL EXPLANATION OF FINDINGS}

Findings showed that majority of the respondents had negative socio-cultural perception about women in beer parlour business. It was observed in Table 2 that a large number of respondents regarded women who engaged in beer parlour business as promiscuous, prostitutes, engaged in indecent business, husband-snatchers among others compared to only a few respondents that saw them as business women. These findings on the socio-cultural perception towards women in beer parlour business is in consonance with an earlier study conducted by Halkias et al., (2011) that gender and culture impede the economic potential of women as entrepreneurs and impact negatively on their enterprise. This is in line with the key postiions of the liberal feminist theory which rests on the belief that the inequalities between men and women assigned by sex are social constructions having no basis in "nature". Thus, the social roles of a woman is that of a mother, wife and homemaker, so the engagement of these 
women in beer parlour business is perceived as unfeminine and this makes them to be negatively perceived as husband snatchers, prostitutes, and conspirator of criminal activities.

\section{CONCLUSION}

The central objective of the study was to examine the socio-cultural perceptions and challenges of women in beer parlour business within Ibadan metropolis. Majority of people perceived them negatively as prostitutes, husband-snatchers, free-ladies, flirts etc. Furthermore, the study revealed that there was no association between the ages, educational level, marital status and religious affiliation of respondents and their perceptions of women in beer parlour business. The study revealed that most women in beer parlour business were perceived negatively (such as regarding them as prostitutes and husband-snatchers) by most female respondents compared to the majority of the male respondents who perceived them as business women. The findings further revealed that clerics of the two major religions in the country have different perceptions about women in beer parlour business. For instance, the doctrine of Islamic religion had a zero or no tolerance for the beer parlour business, while the Christianity religion on the other hand had mixed perceptions. Although, the catholic devotees did not view the business negatively but the Pentecostals on their part described the beer parlour operators as hypocrites and sinners.

\section{RECOMMENDATIONS}

This study has identified the socio-cultural perceptions of women in beer parlour business. Based on these finding, the following recommendations are provided:

1. Good policies and laws capable of changing societal attitudes and beliefs toward women in gendered businesses should be inculcated in the educational and communication media of Nigerian society.

2. There is need for further social research in the area of culture and women's entrepreneurship. Related efforts should go beyond the individual enterprise, to penetrate the community and institutional attitudinal or behavioral and structural levels.

3. There is dire need to encourage industry, employers and educators to fund a provincewide campaign to change the stereotypical perceptions of certain trades and to foster the idea that entrepreneurial activity is a dynamic field for women

\section{References}

Abimbola, O.H. and Agboola, M.G. (2011) 'Environmental factors and entrepreneurship development in Nigeria'. Sustainable Development in Africa 13(4).

Ajayi, 0. (2012) 'Flood management in an urban setting. A case study of Ibadan metropolis. Hydrology for disaster management.' Special Publication of the Nigerian Hydrological Sciences :65-81

Blakely, Kristin (2008) 'Busy brides and the business of family life: The wedding-planning industry and the commodity frontier', Journal of Family Issues 29(5):639-682.

Blundel, R.k, Spence, L.J \& Zerbinati,, S. (2010) Entrepreneurial social responsibility: Scoping the Territory in Spence, L \& Painter-Morland, M. Ethics in Small and Medium Sized Enterprises: A Global Commentary. Dordrecht: Springer

Global Entrepreneurship Monitor (GEM). (2004) Women and Entrepreneurship. Center for Women's leadership. Banson College MA, USA.

Halkials, D., Nwajiuba, C., Harkiolaks, N. and Caracatsanis, N. (2011) Challenges facing entrepreneurs in Nigeria. Women Entrepreneurs in Nigeria. Rev. Emerald Group publishing ltd. 34(2): 221-236.

Makhbul, Z. M. (2011). 'Entreprenuerial Success: An Exploratory Study among Entrepreneurs'. International Journal of Business Management 1(6):1-10

McDowell, L. (2008) 'The New Economy: Class Condescension and Caring Labour: Changing Formations of Class and Gender' NORA-Nordic Journal of Feminist and Gender Research 16 (3):150-165. 
Naude, W. \& Minniti, M. (2011) Examining the Entrepreneur Gender Gap. Economic Development, Female Entrepreneurs in Developing Countries. United Nations University

Nworah, U. (2011). Culture and Igbo Business practices. Sahara Reporters

Press, A. (2009) “The End of Television? Its Impact on the World (So Far): Gender and Family in Television's Golden Age and Beyond." The Annals of the American Academy of Political and Social Science 62(5):139-150.

Ritzer, G \& Stepnisky, J. (2013) Sociological Theory, 9th Edition. New York: Mc-Graw Hill

Théubad, S. (2010) 'Gender and Entrepreneurship as a Career Choice: Do Self-assessment of Ability Matter?' Social Psychology Quarterly 20(10): 1-17

Yusuf, l. (2013). Influence of Gender and Cultural Beliefs on Women Entrepreneurs in Developing Economy. Journal of Business Administration, 3(5):117-127 